\title{
A Functional Haplotype Implicated in Vulnerability to Develop Cocaine Dependence is Associated with Reduced PDYN Expression in Human Brain
}

\author{
Vadim Yuferov*,', Fei Ji', David A Nielsen', Orna Levran', Ann Ho', Susan Morgello ${ }^{3}$, Ruijin Shi ${ }^{3}$, Jurg Ott ${ }^{2,4}$ \\ and Mary Jeanne Kreek' \\ 'Laboratory of the Biology of Addictive Diseases, The Rockefeller University, New York, NY, USA; '2 Laboratory of Statistical Genetics, The \\ Rockefeller University, New York, NY, USA; ${ }^{3}$ Mount Sinai Medical Center, New York, NY, USA; ${ }^{4}$ Beijing Institute of Genomics, Chinese Academy of \\ Sciences, Beijing, China
}

\begin{abstract}
Dynorphin peptides and the $\kappa$-opioid receptor are important in the rewarding properties of cocaine, heroin, and alcohol. We tested polymorphisms of the prodynorphin gene (PDYN) for association with cocaine dependence and cocaine/alcohol codependence. We genotyped six single nucleotide polymorphisms (SNPs), located in the promoter region, exon 4 coding, and $3^{\prime}$ untranslated region, in 106 Caucasians and 204 African Americans who were cocaine dependent, cocaine/alcohol codependent, or controls. In Caucasians, we found point-wise significant associations of 3'UTR SNPs (rs910080, rs910079, and rs2235749) with cocaine dependence and cocaine/ alcohol codependence. These SNPs are in high linkage disequilibrium, comprising a haplotype block. The haplotype CCT was significantly experiment-wise associated with cocaine dependence and with combined cocaine dependence and cocaine/alcohol codependence (false discovery rate, $q=0.04$ and 0.03, respectively). We investigated allele-specific gene expression of PDYN, using SNP rs9 I0079 as a reporter, in postmortem human brains from eight heterozygous subjects, using SNaPshot assay. There was significantly lower expression for $C$ allele (rs9 10079), with ratios ranging from 0.48 to 0.78 , indicating lower expression of the CCT haplotype of PDYN in both the caudate and nucleus accumbens. Analysis of total PDYN expression in 43 postmortem brains also showed significantly lower levels of preprodynorphin mRNA in subjects having the risk CCT haplotype. This study provides evidence that a 3'UTR PDYN haplotype, implicated in vulnerability to develop cocaine addiction and/or cocaine/alcohol codependence, is related to lower mRNA expression of the PDYN gene in human dorsal and ventral striatum.

Neuropsychopharmacology (2009) 34, I |85-I 197; do::I0. I038/npp.2008. I87; published online I5 October 2008
\end{abstract}

Keywords: addiction and substance abuse; molecular and cellular neurobiology; neurogenetics; neurochemistry; cocaine

\section{INTRODUCTION}

Dynorphin and the $\kappa$-opioid receptor (KOPr) are localized in several areas of the dopaminergic nigrostriatal and mesolimbic-mesocortical systems, and involved in a modulatory role in opioid, cocaine and other rewarding stimuli, presumably through modulation of basal and druginduced dopaminergic tone (Kreek et al, 2002). Dynorphin peptides decrease basal and drug-induced dopamine levels in several areas of the dopaminergic nigrostriatal and mesolimbic-mesocortical system. The KOPr-dynorphin system may therefore be considered to be a part of the

*Correspondence: Dr $\vee$ Yuferov, Laboratory of the Biology of Addictive Diseases, The Rockefeller University, 1230 York Avenue, Box 17I, New York, NY 10065, USA, Tel: + I 2123278234 ,

Fax: + I 212327 8574, E-mail: yuferov@rockefeller.edu

Received 30 June 2008; revised 30 August 2008; accepted 17 September 2008 counter-modulatory mechanisms of the brain following direct or indirect drug-induced dopaminergic stimulation (Kreek et al, 2005).

The human prodynorphin gene $(P D Y N)$ is located at chromosome 20pter-p12.2 and spans $15.3 \mathrm{~Kb}$ (GenBank accession number NM_024411). The gene consists of four exons. Exon 1 and exon 2 contain the $5^{\prime}$ untranslated region (UTR), exon 3 encodes a signal peptide, and exon 4 encodes dynorphin peptides, including $\alpha$-neoendorphin, $\beta$-neoendorphin, dynorphin A, and dynorphin B. Dynorphin peptides and prodynorphin mRNA are particularly abundant in the nucleus accumbens, caudate, amygdala, hippocampus, and hypothalamus (Mansour et al, 1994; Hurd, 1996; Akil et al, 1998).

In the human striatum, high expression of the prodynorphin gene was found in GABAergic medium spiny neurons that are organized in two compartments, patches and matrix (Gerfen, 1984). The compartments have separate output pathways: dynorphinergic patch projections terminate 
in the substantia nigra compacta, whereas the substantia nigra reticulata and internal globus receive dynorphinergic terminals from the matrix (Gerfen, 1992). In addition, projection neurons in the striatum can be divided into two subtypes - striatonigral neurons, with projections to the substantia nigra and the globus pallidus interna; and striatopallidal neurons with projections only to the globus pallidus externa (Steiner and Gerfen, 1998). Striatonigral neurons (the direct pathway) express dynorphin and the D1 dopamine receptor, whereas striatopallidal neurons (indirect pathway) express enkephalin and the D2 dopamine receptor. These two pathways regulate basal ganglia output to the thalamus, which in turn projects back to the cerebral cortex (eg Parent and Hazrati, 1995).

Cocaine administration elevates prodynorphin mRNA levels predominantly in rodent caudate putamen following a single injection, self-administration, and acute or chronic 'binge' administration (Sivam, 1989; Hurd et al, 1992; Spangler et al, 1993; Daunais et al, 1993; Daunais and McGinty, 1994; Yuferov et al, 2001). Pretreatment with $\mathrm{KOPr}$ agonists decreases the psychostimulant and conditioned rewarding effects of cocaine in rats, and decreases the rate of intravenous cocaine self-administration (Glick et al, 1995; Schenk et al, 1999; Zhang et al, 2004). Administration of the selective KOPr antagonist nor-BNI did not influence ongoing cocaine self-administration in rodents or primates (Glick et al, 1995; Negus et al, 1997), but decreased the acquisition of cocaine self-administration behavior in rodents (Kuzmin et al, 1998).

The promoter region of the human PDYN gene contains a 68-base pair nucleotide tandem repeat polymorphism (rs35286281), located $1250 \mathrm{bp}$ upstream of exon 1 (Horikawa et al, 1983). This polymorphism, which contains a putative AP-1 transcription complex (c-Fos/c-Jun) binding site, is found in 1-4 copies. An in vitro study, using a minimal PDYN promoter in a reporter gene expression assay, showed that constructs containing three or four copies of the repeat produced approximately 1.5 greater levels of forskolininduced (but not basal) transcriptional activity compared with constructs with one or two copies of the repeat (Zimprich et al, 2000). Several studies have examined an association of this polymorphism with drug dependence with conflicting results. One study showed that Hispanic individuals with three or four copies of the repeat have a lower risk for development of cocaine dependence (Chen et al, 2002). However, two subsequent studies using more stringent diagnostic criteria showed increased risk for cocaine dependence and cocaine/alcohol codependence in African Americans with three or four repeats (Dahl et al, 2005; Williams et al, 2007). These studies demonstrated only a nominal significant association of this polymorphism with drug dependence, with no experiment-wise significance.

Recently, a comprehensive study of PDYN polymorphisms in association with alcohol dependence in a group of 1860 European Americans from 219 alcoholic families was reported (Xuei et al, 2006). In this study, 18 single nucleotide polymorphisms (SNPs) were genotyped across $P D Y N$ from $4 \mathrm{~kb}$ upstream of the transcriptional initiation site to $3 \mathrm{~kb}$ downstream of the $3^{\prime}$ end. None of the SNPs in the coding region altered the amino-acid sequence. Multiple PDYN SNPs located in the promoter and in exon 4 were found to be significantly associated with alcohol depen- dence. A haplotype block of six SNPs in the $3^{\prime}$ UTR was also significantly associated with alcohol dependence. There is no information on the functionality of those polymorphisms.

It has been suggested that inherited variations affecting gene expression may be important in susceptibility to complex disorders, including drug addiction and alcoholism (Knight, 2005; Sadée and Dai, 2005; Le-Niculescu et al, 2007). A number of studies have been performed to elucidate the patterns of genetic variations affecting gene expression in relation to phenotypic variation and disease (Bray et al, 2003; Buckland, 2004; Morley et al, 2004; Pastinen et al, 2005; Wang et al, 2008).

In this study, we tested PDYN polymorphisms for association with vulnerability to develop cocaine dependence and cocaine/alcohol codependence. Objectives of the present study were: (1) to define genotype and allelic frequencies of six known SNPs, located in the PDYN promoter and exon 4 , for study of association with cocaine dependence and cocaine/alcohol codependence in two ethnic groups, African Americans and Caucasians; (2) to investigate differential expression of PDYN mRNA in an allele-specific manner in postmortem brain tissues, and (3) to elucidate the effect of the genotype pattern on the total $P D Y N$ mRNA levels.

\section{MATERIALS AND METHODS}

\section{Study Subjects and Assessments}

The 310 subjects were selected from consecutively recruited nonrelated subjects entering a study on the genetics of addiction conducted at the Laboratory of the Biology of Addictive Diseases at The Rockefeller University. Subjects were recruited in New York City between 26 July 2000 and 25 May 2005. Demography and drug category of study subjects is presented in Table 1a. All subjects gave written informed consent for studies of genetics approved by The Rockefeller University Hospital Institutional Review Board (IRB). All subjects were assessed with regard to medical and psychiatric history. The subjects completed a family history questionnaire in which they self-identified their ethnic/ cultural backgrounds for three generations. Participants were excluded from this study if they had parents, grandparents, and/or great grandparents of different ancestry (defined as mixed or other ancestry).

Diagnoses were made using Diagnostic and Statistical Manual of Mental Disorders (DSM-IV) criteria for cocaine or alcohol dependence set by the American Psychiatric Association, as determined by Structured Clinical Interview for DSM-IV, and the addiction severity index (McLellan et al, 1992). No subjects met dependence or abuse criteria for opiates. Control group subjects were excluded for each of the following criteria: (1) current abuse of alcohol, at least one instance of drinking to intoxication during the previous 30 days; (2) history of alcohol drinking to intoxication or any use of opiates, cocaine, amphetamines, or other illicit drugs more than twice a week, for more than six consecutive months; and (3) cannabis use for more than 12 days before 30 days or past use for more than twice a week for more than 4 years. 
Table I Categorization of samples

\begin{tabular}{|c|c|c|c|c|c|}
\hline Ethnicity & Control & Cocaine dependent & $\begin{array}{l}\text { Cocaine/alcohol } \\
\text { codependent }\end{array}$ & $\begin{array}{l}\text { Combined cocaine dependent } \\
\text { and cocaine/alcohol codependent }\end{array}$ & Total \\
\hline \multicolumn{6}{|c|}{ (a) Demography and categories of subjects in the association study } \\
\hline Caucasians & 65 & 17 & 24 & 41 & 106 \\
\hline Ethnicity & Age & PMI (h) & HIV negative & HIV positive & Total \\
\hline \multicolumn{6}{|c|}{ (b) Demography and categories of postmortem brain samples } \\
\hline African Americans & $50.2 \pm 9.0$ & $12.3 \pm 8.2$ & 3 & 9 & 12 \\
\hline Caucasians & $45.6 \pm 10.1$ & $10.2 \pm 4.9$ & 7 & 6 & 13 \\
\hline Total & & & 18 & 25 & 43 \\
\hline
\end{tabular}

\section{Postmortem Brain Samples}

Brains were obtained within $29 \mathrm{~h}$ of demise from 40 individuals as part of the Manhattan HIV Brain Bank study (The Mount Sinai Medical Center, New York, NY). This program operates under local IRB-approved ethical guidelines, and individuals or their primary next-of-kin give consent for collection and use of brain tissues for medical research and furthering medical knowledge. The facility from which these brains were obtained characterized each brain to the full extent possible. A minimum of 50 sections from each brain were examined by a board-certified neuropathologist (Susan Morgello). Specimens from subjects with protracted agonal state, as manifested by extensive anoxic-ischemic damage on histological evaluation, were excluded from this study.

Coronal sections were stored at $-80^{\circ} \mathrm{C}$. For this study, dissection of the nucleus accumbens and head of caudate was performed under the supervision of a board-certified neuropathologist. In addition to these 40 samples, three brains were obtained through the Mount Sinai autopsy service, as part of the activities of the IRB-approved Alzheimer's Disease Research Center (Dr Daniel Perl, supervising neuropathologist).

Caudate and nucleus accumbens samples were derived from 43 unrelated individuals of mixed ethnicities (13 Caucasians, 12 African Americans, 16 Hispanics, 2 Asians). A total of 25 were HIV seropositive and 18 were HIV negative (Table $1 \mathrm{~b}$ ). A more detailed demographic description of the brain samples, inclusive of ethnicity, age, postmortem interval (PMI), and HIV status of subjects, can be found in Supplementary Table S4.

\section{DNA and RNA Preparation}

A small piece $(40-60 \mathrm{mg}$ ) of each brain sample was homogenized either in DNA lysis buffer (Easy-DNA ${ }^{\mathrm{TM}}$ Kit, Invitrogen, Carlsbad, CA, USA) for isolation of genomic
DNA or RLT buffer (RNeasy ${ }^{\circledR}$ Mini Kit, Qiagen, Valencia, CA, USA) for isolation of total RNA according to the manufacturers' protocols. RNA samples were treated with RNase-Free DNase (TURBO DNA-free ${ }^{\mathrm{TM}}$, Ambion, Austin, TX, USA). Genomic DNA for the case-control association study was extracted from peripheral blood lymphocytes and prepared using buffy-coat lymphocyte isolation from whole blood followed by salt-precipitation DNA extraction.

\section{Brain $\mathrm{pH}$ and RNA Integrity}

The $\mathrm{pH}$ measurements of the brain specimens were made using 270-370 mg tissue samples from the occipital cortex homogenized in $10 \times$ volume of unbuffered deionized $\mathrm{H}_{2} \mathrm{O}$ (Milli-Q Synthesis System, Millipore, Billerica, MA, USA). The homogenates were centrifuged at 5000 r.p.m. for $5 \mathrm{~min}$ at $4{ }^{\circ} \mathrm{C}$ and equilibrated to room temperature. The $\mathrm{pH}$ was measured with $\mathrm{pH} 211$ meter (Hanna Instruments, Woonsocket, RI, USA) calibrated with two standard buffer solutions of pHs 4.01 and 7.01. The RNA integrity number (RIN) and concentration were determined using Agilent 2100 Bioanalyzer (Agilent Technologies, Waldbronn, Germany).

\section{PCR, Sequencing and Genotyping}

The location of the six common PDYN SNPs examined are shown in Figure 1a, and are listed in Table 2. Three sets of forward and reverse primers for amplification and sequencing of part of the PDYN promoter region and exon 4, including $3^{\prime}$ UTR, are shown in Supplementary Table S1. Oligonucleotide primers were designed using the program Oligo 4.0 (National Biosciences Inc., Plymouth, MN, USA) and synthesized by Gene Link (Hawthorne, NY, USA). Standard PCR was performed using Platinum ${ }^{\circledR}$ Taq PCRx DNA Polymerase Kit (Invitrogen) and DNA extracted from peripheral blood lymphocytes. Amplified PCR DNA fragments were purified using the QIAquick PCR Purification 


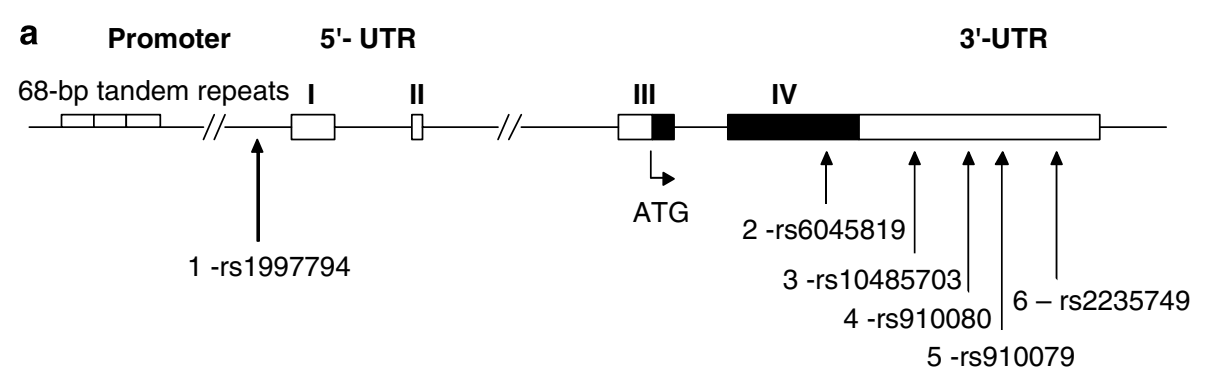

b Caucasian controls $(n=65)$

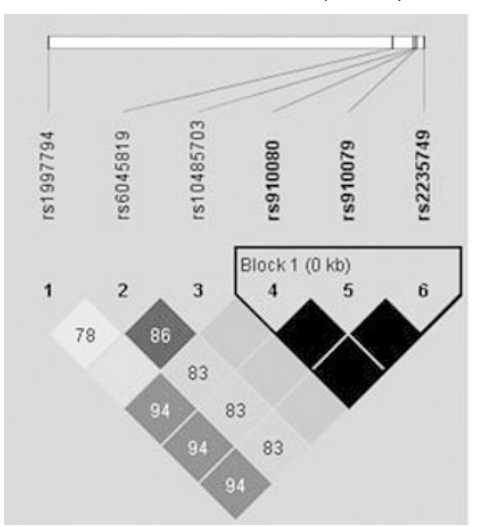

African American controls $(n=76)$

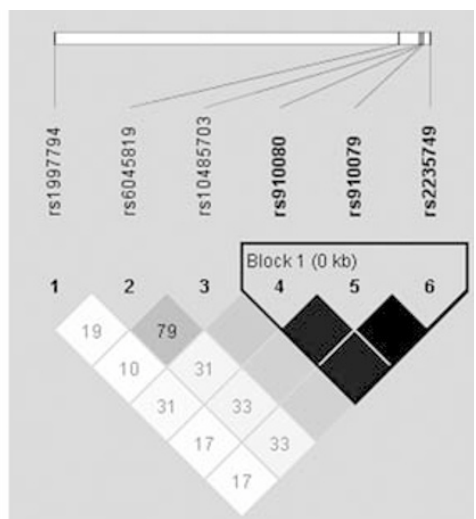

Figure I (a) Genomic structure of the PDYN gene and location of genotyped polymorphisms. Single nucleotide polymorphism (SNP) rs9 I0079 was used in the allele-specific gene expression analysis. The black boxes represent the coding regions. (b) Haploview-generated linkage disequilibrium (LD) patterns of six SNPs and predicted block structure in Caucasian and African-American control subjects. Number in each box represents $D^{\prime}$ value $(\times 100)$ for each SNP pair. Black boxes represent $D^{\prime}=1$ and $r^{2}=1$. Shades of gray boxes from dark to light represent decreasing LD values. Results $\left(D^{\prime}\right.$ and $\left.r^{2}\right)$ of pairwise $L D$ analysis for the consecutive SNPs are presented in Supplementary Table S6.

Table 2 Distribution of PDYN Gene Variants in Control Subjects

\begin{tabular}{|c|c|c|c|c|c|c|}
\hline \multirow[b]{2}{*}{$\begin{array}{l}\text { Variant } \\
\text { number }\end{array}$} & \multirow[b]{2}{*}{ Variant ID } & \multirow[b]{2}{*}{$\begin{array}{l}\text { Location } \\
\text { on chr } 20^{\mathrm{a}}\end{array}$} & \multirow[b]{2}{*}{$\begin{array}{l}\text { PDYN gene } \\
\text { location }\end{array}$} & \multirow[b]{2}{*}{ Variation } & \multicolumn{2}{|c|}{ Minor allelic frequency } \\
\hline & & & & & $\begin{array}{l}\text { Caucasian } \\
(n=65)\end{array}$ & $\begin{array}{c}\text { African American } \\
(n=76)\end{array}$ \\
\hline । & rs 1997794 & 1922858 & Promoter & $\mathrm{A} / \mathrm{G}^{\mathrm{b}}$ & 0.32 & 0.22 \\
\hline 2 & rs6045819 & 1909134 & Exon 4 & $\mathrm{~T}>\mathrm{C}^{\mathrm{c}}$ & 0.07 & 0.28 \\
\hline 3 & rs 10485703 & 1908313 & Exon 4-3'UTR & $T>C$ & 0.06 & 0.16 \\
\hline 5 & rs910079 & 1908198 & Exon $4-3^{\prime} \cup T R$ & $\mathrm{~T}>\mathrm{C}$ & 0.21 & 0.46 \\
\hline 6 & rs2235749 & 1907939 & Exon 4-3'UTR & $\mathrm{C}>\mathrm{T}$ & 0.21 & 0.46 \\
\hline
\end{tabular}

avariant location from dbSNP database (NCBI), Genome Build 36.3.

${ }^{b} \mathrm{G}$ is a minor allele in Caucasians; it is a major allele in African Americans.

'A synonymous mutation in the codon for the amino acid His 200.

Kit (Qiagen), and subsequently sequenced in both orientations using the ABI BigDye Terminator Cycle Sequencing Kit and ABI Prizm 3700 DNA Analyzer (Applied Biosystems, Foster City, CA). The resulting electropherograms were analyzed using Seqman ${ }^{\mathrm{TM}}$ DNAStar software (DNAStar, Madison, WI, USA).

\section{Allele-Specific Gene Expression Assay}

Measurements of allele-specific mRNA expression in brain tissues were carried out using $\mathrm{SNaPshot}^{\circledR}$ Multiplex Kit
(Applied Biosystems), essentially as described (Zhang et al, 2005; Bray and O'Donovan, 2006). This method involves two steps. The first step is the PCR amplification of the region including the exonic SNP rs910079 in genomic DNA or cDNA. The second step involves a single-base extension of a primer adjacent to rs910079 in the presence of fluorescently labeled nucleotides in PCR products generated with CDNA and genomic DNA, and analysis of extended primers on a DNA sequence analyzer ABI 3730. This quantitative method for measurements of relative allelic expression was applied to subjects who are heterozygous for rs910079. 
cDNA was generated from $1 \mu \mathrm{g}$ total RNA extracted from brain tissues in $20 \mu \mathrm{l}$ reaction mixes containing $1 \mu \mathrm{l}(200 \mathrm{U})$ SuperScript III $^{\mathrm{TM}}$ reverse transcriptase (Invitrogen), $1 \mu \mathrm{l}$ of $50 \mu \mathrm{M}$ oligo $(\mathrm{dT})_{20}$ primer, $1 \mu \mathrm{l}$ of $10 \mathrm{mM}$ dNTP mix, $1 \mu \mathrm{l}$ (12 pg) of PDYN mRNA-specific primer (5'-CTTTCTGG TTTTATTTTGAGACA-3', located $1120 \mathrm{bp}$ downstream of the termination codon), $4 \mu \mathrm{l}$ of $5 \times$ first-strand buffer (Invitrogen), $1 \mu \mathrm{l}$ of RNaseOUT $(40 \mathrm{U} / \mu \mathrm{l})$ at $50^{\circ} \mathrm{C}$ for $45 \mathrm{~min}$.

PCR fragments (154 bp) were generated by amplification of both the cDNA and genomic DNA containing the SNP rs910079 using the forward primer $5^{\prime}$-ACCCTGGACAGTGC CTAACT- $3^{\prime}$, and the reverse primer $5^{\prime}$-GAGGGAA CTGGTCC!QJ;ACATTT-3' with the following thermal profile: 1 cycle for $3 \mathrm{~min}$ at $95^{\circ} \mathrm{C} ; 35$ cycles at $95^{\circ} \mathrm{C} / 30 \mathrm{~s}$, at $51^{\circ} \mathrm{C} /$ $30 \mathrm{~s}, 72^{\circ} \mathrm{C} / 30 \mathrm{~s}$ ), and $1 \mathrm{cycle}$ at $72^{\circ} \mathrm{C}$ for $7 \mathrm{~min}$. To remove dNTPs and primers used for amplification, PCR products were analyzed on $1.5 \%$ agarose gel, and DNA fragments of expected size were cut out from the gel, and purified using QIAquick Gel Extraction Kit (Qiagen).

Primer extension assays were carried out using SNaPshot Multiplex Kit (Applied Biosystems), and the extension forward primer $5^{\prime}$-CTTACAGAAGGGAGTGAAAACC- $3^{\prime}$ for rs910079 (Figure 1a, Table 2) for both genomic and cDNA with the following thermal profile: 25 cycles at $96^{\circ} \mathrm{C} / 10 \mathrm{~s}$, $50^{\circ} \mathrm{C} / 5 \mathrm{~s}$, and $60^{\circ} \mathrm{C} / 10 \mathrm{~s}$. Unincorporated dNTP were removed by incubation with $1.0 \mathrm{U}$ of antarctic alkaline phosphatase (New England Biolabs, Ipswich, MA, USA) at $37^{\circ} \mathrm{C}$ for $40 \mathrm{~min}$. The primer extension products were resolved by capillary electrophoresis using an ABI 3730 DNA Analyzer and quantified using the Gene Mapper 3.0 software (Applied Biosystems). Peak area ratios were calculated to measure the relative amount of the fragments containing the two alleles.

Because of differences in fluorescence yields and efficiency of terminator nucleotide incorporation, peak area ratios of genomic DNA differed from the theoretical ratio of 1.0. The measured ratios for cDNA were therefore normalized by dividing each measured ratio by the mean of measured genomic DNA ratios. For each subject, allelic ratios of PDYN CDNA were determined in triplicate from three independent syntheses of $\mathrm{cDNA}$, providing nine measurements.

\section{Solution Hybridization Ribonuclease Protection- Trichloroacetic Acid (TCA) Precipitation Assay}

PDYN mRNA levels in the caudate and nucleus accumbens were measured by the solution hybridization RNase protection assay, essentially as described (Branch et al, 1992; Yuferov et al, 2001). The template for in vitro synthesis of the antisense cRNA and sense RNA transcript was a $737 \mathrm{bp}$ fragment of cDNA containing $200 \mathrm{bp}$ of exon 4 and $537 \mathrm{bp}$ of the $3^{\prime}$ UTR (bases 788-1525, GenBank Accession number NM_024411), cloned into the pSP65 plasmid vector (Promega, Madison, WI, USA) in both orientations. The antisense ${ }^{33} \mathrm{P}$-labeled hybridization probe was synthesized with SP6 RNA polymerase, $\left[\alpha_{-}{ }^{33} \mathrm{P}\right]$ GTP (3000 Ci/mmol; Perkin-Elmer, Boston, MA), and components of the Riboprobe ${ }^{\circledR}$ System-SP6 (Promega). A stock of dilutions of the sense transcripts of known concentration were used as calibration standards. The antisense ${ }^{33} \mathrm{P}$ labeled cRNA probe was hybridized in duplicate to a set of calibration standards (from 0.625 to $80 \mathrm{pg}$ ) and with duplicate RNA brain samples in $10 \mathrm{mM}$ Tris- $\mathrm{HCl}(\mathrm{pH} \mathrm{7.4)}$, $10 \mathrm{mM}$ EDTA, $0.3 \mathrm{M} \mathrm{NaCl}$, and $0.5 \%$ sodium dodecyl sulfate at $75^{\circ} \mathrm{C}$ for $16 \mathrm{~h}$. Following hybridization, samples were treated with RNase A $(40 \mu \mathrm{g} / \mathrm{ml})$ and RNase T1 $(2 \mu \mathrm{g} / \mathrm{ml})$ in $0.3 \mathrm{M} \mathrm{NaCl}, 5 \mathrm{mM}$ EDTA, $10 \mathrm{mM}$ Tris- $\mathrm{HCl}(\mathrm{pH} 7.5)$ at $30^{\circ} \mathrm{C}$ for $1 \mathrm{~h} .{ }^{33} \mathrm{P}$-labeled cRNA-mRNA hybrids were then precipitated in 5\% TCA, $0.75 \%$ sodium pyrophosphate, and $0.02 \%$ bovine serum albumin and collected on $934 \mathrm{AH}$ Whatman filters using a cell harvester (Brandel, Gaithersburg, MD, USA). After washing the filter with 5\% TCA, the radiolabeled protected RNA hybrids were counted by liquid scintillation. The counts per minute $(\mathrm{cpm})$ values were transformed to pg quantities of mRNA using linear regression from the calibration curve.

The procedure for determining the concentration of total RNA in brain extracts was similar to that described above, except that duplicate dilutions of each brain tissue RNA extract were hybridized to the ${ }^{33} \mathrm{P}$-labeled antisense $18 \mathrm{~S}$ ribosomal RNA probe and dilutions of a brain total RNA of known concentration, from 1.25 to $80 \mathrm{ng}$, were used to generate a standard curve. The content of PDYN mRNA in samples tested was expressed as pg of mRNA per $\mu \mathrm{g}$ total RNA.

\section{Statistical Analysis}

Haploview 4.1 (Barrett et al, 2005) was used to generate linkage disequilibrium (LD) plots of six variants and haplotype blocks using the Gabriel method (Gabriel et al, 2002). The haplotype case-control association results were also obtained using Haploview 4.1. The program PLINK 1.03 (http://pngu.mgh.harvard.edu/purcell/plink/; Purcell et al, 2007) was used to verify the results of Haploview haplotype association tests. We started haplotype-based association analysis with three $3^{\prime}$ UTR SNPs which are in high LD. To test the hypothesis that SNP rs1997794 may have a cis-regulatory function, we analyzed this SNP with the $3^{\prime}$ UTR SNPs.

The Pearson's $\chi^{2}$-test was applied to assess the significance of the genotypic and allelic association of each variant, using SAS 9.1 (http://www.sas.com). To correct for multiple testing, the program QVALUE 1.0 (Storey, 2002; Storey and Tibshirani, 2003; Storey et al, 2004) was applied to all association tests to calculate the false discovery rate (FDR) (ie genotypic, allelic, and haplotype) across the ethnic groups studied. A $q$-value $<5 \%$ was considered experiment-wise significant.

\section{RESULTS}

\section{PDYN SNP Genotyping and Association Results}

We genotyped six PDYN polymorphisms in 204 African Americans and 106 Caucasians (Table 1a). Minor allelic frequencies of the six variants in controls are shown in Table 2. No significant deviation from Hardy-Weinberg equilibrium was found in the control group of either ethnicity. There is a significant difference in allelic distribution between ethnicities in control subjects (Pearson's $\chi^{2}$-test, $\mathrm{df}=1, p<0.0001$ for SNPs $1-6$ ). 
Next, we tested the six $P D Y N$ variants for association with cocaine dependence and cocaine/alcohol codependence. These variants are located in the PDYN promoter, $-301 \mathrm{~A} /$ $\mathrm{G}$ (rs1997794), and in the coding region of exon 4 (rs6045819) and the exon 4-3'UTR (rs10485703, rs910080, rs910079, and rs2235749) (Figure 1a; Table 2). We found significant point-wise association of five variants (rs6045819, rs10485703, rs910080, rs910079, and rs2235749) with cocaine dependence or cocaine/alcohol codependence in Caucasians, but not in African Americans. Table 3 summarizes the results of the tests for association by genotypes and alleles in Caucasians. Complete results in Caucasian and African American groups are shown in Supplementary Tables S2 and S3, respectively.

The SNP rs6045819 genotype showed a point-wise association with cocaine dependence and the combined cocaine dependence and cocaine/alcohol codependence $(p=0.044$ and 0.022 , respectively), and experiment-wise association $(q=0.048)$ with the combined dependencies (Table 3). At the allelic level, there was a significant association of this SNP with the combined dependencies (point-wise $p=0.038, \quad \mathrm{OR}=2.53,95 \% \mathrm{CI}=1.03-6.23$ ). Using genotype and allelic association tests, we found also an experiment-wise significant association of the variant rs 10485703 with cocaine dependence $(q=0.048, \mathrm{OR}=3.27$,
95\% CI $=1.05-10.17)$. The most significant association with cocaine dependence and cocaine/alcohol codependence was found in the analysis of genotype and allelic frequencies of the SNPs in $3^{\prime}$ UTR, rs910080, rs910079, and rs 2235749 (Table 3). Owing to nearly complete $\mathrm{LD}$, association tests of these three SNPs showed similar results.

There were experiment-wise significant associations of genotypes and alleles of rs910079, and rs2235749 variants with all case groups $(q=0.029-0.048, \mathrm{OR}=2.44-2.29)$. Experiment-wise associations for both genotypes and alleles of rs910080 were found in the cocaine dependent and combined dependencies groups $(p=0.034-0.042)$. There was no significant difference in the distribution of rs $1997794(-301 \mathrm{~A} / \mathrm{G})$ in the PDYN promoter between the control and the cocaine or cocaine/alcohol codependent groups in either Caucasians or African Americans (Supplementary Tables S2 and S3).

\section{Haplotype Analysis}

We have examined LD structure of the $14 \mathrm{~kb} P D Y N$ region containing six variants, using the Haploview program. The variants rs910080, rs910079, and rs2235749 in the $3^{\prime}$ UTR were in complete LD in the Caucasian control group $\left(D^{\prime}=1.0, r^{2}=1.0\right)$, and in high LD in the African-American

Table 3 Asssociation of Single PDYN SNPs with Cocaine Dependence and Cocaine/Alcohol Codependence in Caucasians

\begin{tabular}{|c|c|c|c|c|c|c|}
\hline \multirow[b]{2}{*}{ SNP ID } & \multirow[b]{2}{*}{$\begin{array}{l}\text { Comparison } \\
\text { with controls }\end{array}$} & \multicolumn{2}{|c|}{ Genotype test } & \multicolumn{2}{|c|}{ Allele test } & \multirow[b]{2}{*}{$O R^{b}(95 \% \mathrm{Cl})$} \\
\hline & & $\begin{array}{l}\text { Point-wise } \\
\text { p-value }\end{array}$ & $\begin{array}{c}\text { FDR }^{\mathbf{a}} \\
q \text {-value }\end{array}$ & $\begin{array}{l}\text { Point-wise } \\
\text { p-value }\end{array}$ & $\begin{array}{c}\text { FDR }^{\mathbf{a}} \\
\text { q-value }\end{array}$ & \\
\hline rs|997794 & Cocaine & 0.7746 & 0.3517 & 0.4594 & 0.2722 & $1.34(0.61-2.94)$ \\
\hline \multirow[t]{2}{*}{$A>G$} & Cocaine/alcohol & 0.2675 & 0.1764 & 0.0767 & 0.0812 & $1.84(0.93-3.62$ \\
\hline & Combined & 0.3110 & 0.1977 & 0.0994 & 0.0936 & $1.62(0.9 \mid-2.87)$ \\
\hline rs6045819 & Cocaine & 0.0443 & 0.0535 & 0.0534 & 0.0622 & $2.88(0.95-8.76)$ \\
\hline \multirow[t]{2}{*}{$\mathrm{T}>\mathrm{C}$} & Cocaine/alcohol & 0.0935 & 0.0908 & 0.1128 & 0.0986 & $2.30(0.80-6.56)$ \\
\hline & Combined & 0.0218 & 0.0479 & 0.0378 & 0.0529 & $2.53(1.03-6.23)$ \\
\hline rsl0485703 & Cocaine & 0.0238 & 0.0479 & 0.0328 & 0.0479 & $3.27(1.05-10.17)$ \\
\hline rs910080 & Cocaine & 0.0329 & 0.0479 & 0.0144 & 0.0419 & $2.67(1.20-5.97)$ \\
\hline \multirow[t]{2}{*}{$\mathrm{T}>\mathrm{C}$} & Cocaine/alcohol & 0.0161 & 0.0433 & 0.0444 & 0.0535 & $2.09(1.01-4.33)$ \\
\hline & Combined & 0.0033 & 0.0287 & 0.0067 & 0.0335 & $2.32(1.25-4.29)$ \\
\hline rs910079 & Cocaine & 0.0329 & 0.0479 & 0.0144 & 0.0419 & $2.67(1.20-5.97)$ \\
\hline \multirow[t]{2}{*}{$\mathrm{T}>\mathrm{C}$} & Cocaine/alcohol & 0.0276 & 0.0479 & 0.0227 & 0.0479 & $2.29(||.|-4.7|)$ \\
\hline & Combined & 0.0041 & 0.0287 & 0.0039 & 0.0287 & $2.44(|.32-4.5|)$ \\
\hline rs2235749 & Cocaine & 0.0329 & 0.0479 & 0.0144 & 0.0419 & $2.67(1.20-5.97)$ \\
\hline$C>T$ & Cocaine/alcohol & 0.0276 & 0.0479 & 0.0227 & 0.0479 & $2.29(||.|-4.7|)$ \\
\hline
\end{tabular}

${ }^{\mathrm{a} F D R}, p<0.05$ experiment-wise.

${ }^{b}$ Odd ratios calculated using minor allele. 
control group $\left(D^{\prime}=1.0, r^{2}=0.89-1.0\right)$, comprising a single haplotype block (Figure 1b). The relative frequencies of the CCT and TTC haplotypes differ between Caucasian and African-American control groups, suggesting that there is an ethnic difference in the PDYN haplotype structure (Table 4).

Haplotype analysis of these variants revealed significant association of the haplotype with cocaine dependence and cocaine/alcohol codependence. There were point-wise associations of the haplotype CCT with cocaine dependence and cocaine/alcohol codependence $(p=0.0144$ and 0.0444 , respectively) (Table 4). The most significant association of this haplotype was found with the combined dependencies (experiment-wise $q=0.0335, \quad \mathrm{OR}=2.32, \mathrm{CI}=1.25-4.29$ ). The frequency of the complementary haplotype block TTC was higher in controls (point-wise $p=0.0039, \mathrm{OR}=0.41$, $\mathrm{CI}=0.22-0.78)$. These results suggest that CCT is a risk haplotype, whereas TTC is a protective haplotype in the development of cocaine dependence and cocaine/alcohol codependence.

The variant rs1997794 (SNP1) in the PDYN promoter region did not belong to the haplotype block in the $3^{\prime}$ UTR. However, this SNP showed a strong correlation with SNPs 4, 5 , and 6 in $3^{\prime}$ UTR in the Caucasian controls $\left(D^{\prime}=0.94\right.$, $\left.r^{2}=0.50\right)$, but not in African-American controls $\left(D^{\prime}=0.17\right.$ $\left.0.31, r^{2}=0.01-0.02\right)$ (Figure 1b, Supplementary Table S6). Of note, similar LD values for these SNPs in both ethnic groups were reported in the HapMap database (Supplementary Table S6). The frequencies of the four SNP haplotypes containing the $3^{\prime}$ UTR SNPs (rs910080, rs910079, and rs2235749) and the promoter SNP1 (rs1997794) differ between the Caucasian and AfricanAmerican control groups (Table 5). Indeed, in Caucasians, the haplotype ATTC was more frequent in control subjects compared with cases $(q=0.0415, \mathrm{OR}=0.4895 \% \mathrm{CI}=0.27$ 0.84 ), and GCCT was more frequent in cases, although it was not significant $(q=0.0634)$. This was not found in African Americans. In association tests, we used the program PLINK 1.03 to verify the results of Haploview haplotype association tests. The results from both programs are remarkably similar as can be seen in Tables 4 and 5 .

Analysis of the PDYN promoter sequence for putative transcription factor binding sites using the Transcription Element Search System (http://www.cbil.upenn.edu/cgi-bin/ tess/tess) showed that the minor G-allele of rs1997794 eliminates a putative binding site TGTGTCA for the AP-1 transcription complex, and may be involved in regulation of gene expression.

Table 4 Association of the PDYN Haplotypes with Cocaine Dependence or Cocaine/Alcohol Codependence

\begin{tabular}{|c|c|c|c|c|c|}
\hline Haplotype 3'UTR & Controls $n(f)$ & Cases $n(f)$ & Haploview (PLINK) point-wise, $p$ & FDR q-value & OR (95\%) \\
\hline \multicolumn{6}{|l|}{ (A) Caucasians } \\
\hline \multicolumn{6}{|l|}{ Cocaine dependent } \\
\hline TTC & $103(0.79)$ & $20(0.59)$ & & & \\
\hline$\pi C^{c}$ & $103(0.79)$ & $31(0.65)$ & & & \\
\hline \multicolumn{6}{|l|}{ Combined case } \\
\hline ССТ & $27(0.21)$ & $31(0.38)$ & $0.0067(0.0056)$ & $0.0335^{b}$ & $2.32(1.25-4.29)$ \\
\hline$\pi C^{c}$ & $103(0.79)$ & $51(0.62)$ & & & \\
\hline ССТ & $66(0.43)$ & $65(0.53)$ & $0.1045(0.1045)$ & 0.0937 & $1.49(0.92-2.40)$ \\
\hline TTC & $86(0.57)$ & $57(0.47)$ & & & \\
\hline \multicolumn{6}{|c|}{ Cocaine/alcohol codependent } \\
\hline ССТ & $66(0.43)$ & $53(0.40)$ & $0.5077(0.5077)$ & 0.2862 & $0.85(0.53-1.37)$ \\
\hline Non-CCT ${ }^{c}$ & $86(0.57)$ & $81(0.60)$ & & & \\
\hline \multicolumn{6}{|l|}{ Combined case } \\
\hline CCT & $66(0.43)$ & I $18(0.46)$ & $0.5999(0.5999)$ & 0.2996 & I.II (0.74-1.67) \\
\hline Non-CCT ${ }^{c}$ & $86(0.57)$ & $138(0.54)$ & & & \\
\hline
\end{tabular}

$n$, number of subjects; $f$, frequency.

aThe order of SNPs in haplotypes is rs910080, rs910079, and rs2235749, respectively.

${ }^{\mathrm{b}} \mathrm{FDR}, p<0.05$ experiment-wise.

Including one subject with the haplotype TCT. 
Table 5 Association of Four SNP Haplotypes of PDYN with Combined Cases

\begin{tabular}{|c|c|c|c|c|c|}
\hline Haplotype & Controls, $n(f)$ & $\begin{array}{l}\text { Combined } \\
\text { cases, } n(f)\end{array}$ & $\begin{array}{l}\text { Haploview (PLINK) } \\
\text { point-wise, } p\end{array}$ & FDR $q$-value & OR (95\% Cl) \\
\hline \multicolumn{6}{|c|}{ (A) Caucasians } \\
\hline GCCT & $25.7(0.24)$ & $25.7(0.32)$ & $0.0562(0.0497)$ & 0.0634 & $1.85(0.98-3.50)$ \\
\hline GTTC & $15.3(0.12)$ & $9.3(0.12)$ & 0.93||$(0.966 \mid)$ & $0.377 \mid$ & $0.96(0.40-2.28)$ \\
\hline \multicolumn{6}{|c|}{ (B) African Americans } \\
\hline GTTC & $61.9(0.4 I)$ & $87.7(0.35)$ & $0.2177(0.1993)$ & 0.1492 & $0.77(0.5 \mid-1.17)$ \\
\hline GCCT & $54.5(0.36)$ & $87.1(0.34)$ & $0.7058(0.6717)$ & 0.3289 & $0.92(0.61-1.40)$ \\
\hline ATTC & $20.1(0.13)$ & $41.3(0.16)$ & $0.4240(0.4388)$ & 0.2555 & $1.26(0.7 \mid-2.24)$ \\
\hline $\mathrm{ACCT}$ & I I.5 (0.08) & $30.9(0.12)$ & $0.1489(0.1544)$ & 0.1107 & I.67 (0.83-3.4I) \\
\hline
\end{tabular}

$n$, number of subjects; $f$, frequency.

aThe SNP order in haplotypes are rs1997794, rs910080, rs910079, and rs2235749, respectively.

${ }^{b} \mathrm{FDR}, p<0.05$ experiment wise.
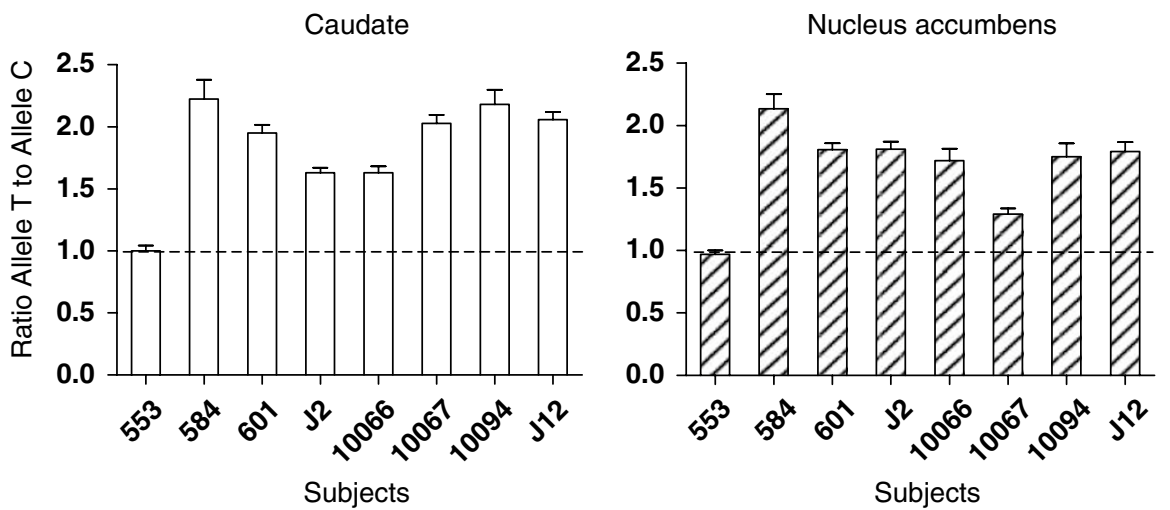

Figure 2 Relative allelic expression of PDYN polymorphism (SNP) rs910079 in RNA extracted from two regions in human postmortem brain of eight heterozygous subjects. Ratios of T-C alleles in each cDNA sample were normalized by reference to genomic allelic ratios. Data shown are the mean \pm SD, and individual data are shown in Supplementary Table 5S.

Two SNPs were not included in haplotype analyses because neither rs6045819 nor rs10485703 are in high LD with the $3^{\prime}$ UTR SNPs $\left(r^{2}=0.20-0.25\right)$ or the $5^{\prime}$ UTR SNP rs1997794 $\quad\left(r^{2}=0.10-0.14\right) \quad$ (Supplementary Table S6). Further, our analyses showed low LD between the VNTR (68-bp tandem repeats, Figure 1a) in the PDYN promoter and SNPs in $3^{\prime}$ UTR in both control populations, Caucasian $\left(D^{\prime}=0.29, r^{2}=0.04\right)$ and African American $\left(D^{\prime}=0.21\right.$, $r^{2}=0.03$ ). Since there is a recent paper from our laboratory which examined association of VNTR with cocaine addiction (Williams et al, 2007), we did not consider the VNTR for further analyses.

\section{Allele-Specific PDYN Gene Expression Analysis in Postmortem Brain Tissues}

To investigate a potential functional (cis-acting) role of the risk haplotype for development of cocaine dependence and cocaine/alcohol codependence, we assessed SNP rs910079 for allele-specific gene expression using the SNaPshot assay. This quantitative method of allele discrimination can only be applied to mRNA from individuals who are heterozygous for the SNP under study. In this assay, the expression level of one allele is compared with the expression level of the other allele in the same sample. For testing cis-acting SNPs in the PDYN gene, DNA and RNA were isolated from the caudate and nucleus accumbens of postmortem brain from 43 unrelated subjects (Table $1 \mathrm{~b}$ and Supplementary Table S4). To characterize the quality of the brain tissues and the integrity of isolated total RNA, we measured $\mathrm{pH}$ of the tissue extracts, and analyzed RNA integrity (RIN). Brain tissue $\mathrm{pH}$ and RIN for each specimen are presented in Supplementary Table S4. A total of 33 tissue specimens out of 40 had $\mathrm{pH}$ values in the range of 6.5-7.4, and seven specimens were in the range of 6.03-6.42. Also, 36 RNA samples out of 43 had RIN values in the range of 6.5-9.5, and seven samples had RIN in the range of 5.0-6.3.

All brain DNA samples were genotyped for the variants 1-6 (Table 2). For SNPs 4, 5, and 6 (rs910080, rs910079, and rs2235749); seven individuals had the CC-CC-TT, 15 individuals had the TT-TT-CC, and 19 subjects had the TC-TC-CT genotype pattern (Supplementary Table S4). Two 
subjects had a TT-TC-CT genotype pattern. Because these SNPs are in high LD, we used SNP 5 (rs910079, Figure 1a), located in the middle of the haplotype block (Figure 1b), as a reporter SNP in the allele-specific gene expression assay.

A subset of seven subjects with heterozygous genotype pattern TC-TC-CT and one subject (no. 553, Supplementary Table S4) with TT-TC-CT genotype were tested in an allelespecific gene expression assay. Subjects with the TC-TC-CT genotype showed differential expression of the PDYN rs910079 alleles in both the caudate and nucleus accumbens (Figure 2). The subject with TT-TC-CT genotype did not show a difference in allelic expression. To calculate relative expression of the two alleles in each sample, the ratio of cDNA peak areas was normalized by use of the average genomic allelic ratio. Allelic ratios in genomic DNA using the forward extension primer yielded an average ratio of $1.0 \pm 0.10 \mathrm{SD}$. Allelic ratios in $\mathrm{cDNA}$ had the mean $\pm \mathrm{SD}$. Ratio of T-C alleles ranged from $1.59 \pm 0.11$ to $2.23 \pm 0.31$ in the caudate, and from $1.29 \pm 0.08$ to $2.14 \pm 0.23$ in the nucleus accumbens. Peak area ratios of genomic DNA and cDNA of the caudate and nucleus accumbens samples for each individual are shown in Supplementary Table S5. The average allelic $\mathrm{T}-\mathrm{C}$ ratio in heterozygous samples was $65 \%$ of $\mathrm{T}$ variant and $35 \%$ of $\mathrm{C}$ variant of PDYN mRNA. These results provided evidence for higher expression of the $\mathrm{T}$ variant of PDYN, which is more common in Caucasians, and lower gene expression of the minor $\mathrm{C}$ allele, respectively.

\section{Effect of the PDYN Variants on Total Preprodynorphin mRNA Expression in Striatum}

The levels of PDYN mRNA in the caudate from 43 postmortem brains measured using a quantitative solution hybridization RNase protection assay are shown in Supplementary Table S4. Results of regression analyses of $P D Y N$ mRNA levels with brain tissue $\mathrm{pH}$ or integrity of RNA (RIN) are shown in Figure 3. There was no significant correlation of PDYN mRNA levels with $\mathrm{pH}$ of brains studied $(r=0.059)$ or with RIN $(r=0.152)$.

To explore whether the PDYN variant, which showed allele-specific gene expression, impacts total gene expression, we grouped mRNA levels in the caudate by genotype pattern (Figure 4). Analysis of variance showed significant differences in PDYN mRNA levels between subjects with different genotype patterns (main effect of genotype, $\mathrm{F}(2,40=11.18, p<0.0002)$. Subjects having homozygous diplotype CC-CC-TT had lower PDYN mRNA levels in the caudate than individuals with homozygous diplotype TTTT-CC $(p<0.005$, Newman-Keuls post hoc test). Also, subjects having the heterozygous diplotypes TC-TC-CT and/or TT-TC-CT had lower PDYN mRNA levels in the caudate than individuals with the TT-TT-CC diplotype $(p<0.002$, Newman-Keuls post hoc test). These results indicate that subjects with the haplotype CCT have lower PDYN expression.

\section{DISCUSSION}

Most studies on association of PDYN polymorphisms with cocaine or heroin dependence have been focused on the 68-

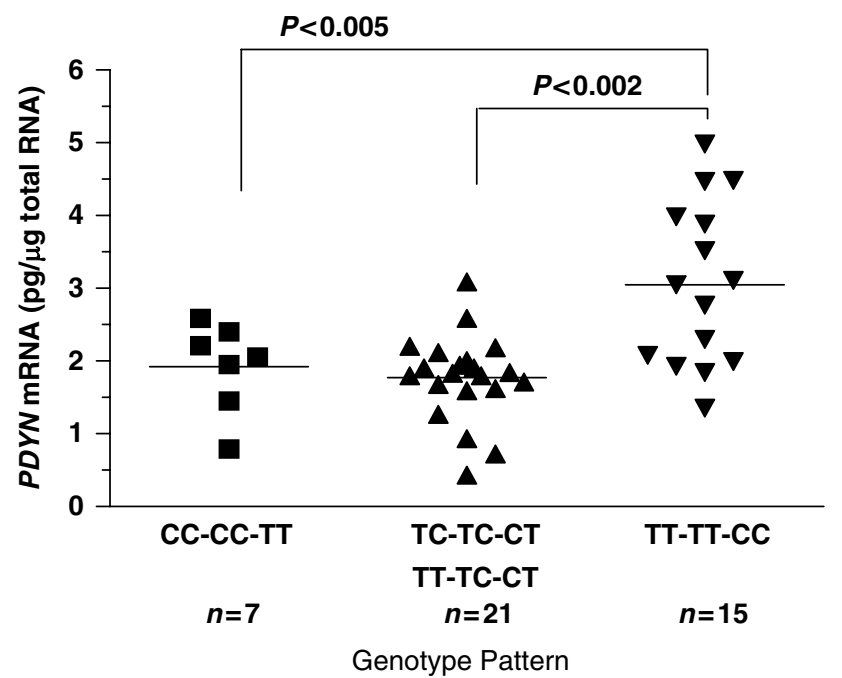

Figure 4 Total PDYN mRNA expression in the caudate from postmortem brains grouped by genotype pattern. mRNA levels were measured by the quantitative solution hybridization RNase protection assay. Genotype patterns comprise the $3^{\prime} \mathrm{UTR}$ polymorphisms (SNPs) (rs910080, rs910079, and rs2235749, respectively). Analysis of variance showed significant difference in PDYN mRNA levels between subjects with different genotype patterns (main effect of genotype, $F(2,37)=9.98$, $p<0.005)$.
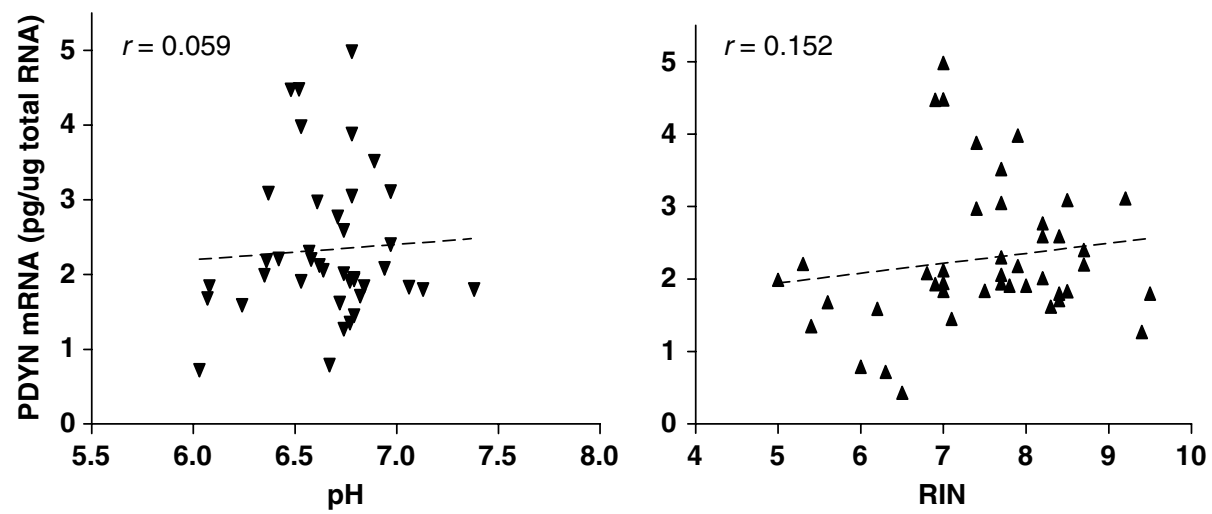

Figure 3 Regression analyses of PDYN mRNA levels with brain tissue $\mathrm{pH}$ or RNA integrity index (RIN). The values of pH and RIN for each specimen are shown in Supplementary Table S4. 
bp tandem repeat variation ( $\mathrm{rs35286281)}$ in the promoter region (Chen et al, 2002; Dahl et al, 2005; Ray et al, 2005; Williams et al, 2007). However, those studies demonstrated only nominally significant $p$-values for associations.

In this study, we genotyped six common PDYN variants in Caucasians and African Americans, previously shown to be associated with alcohol dependence in Caucasians (Xuei et al, 2006). In genotype and allelic tests, we found experiment-wise significant association of three SNPs (rs910080, rs910079, and rs2235749) in the $3^{\prime}$ UTR with both cocaine dependence and cocaine/alcohol codependence and in the combined case group in Caucasians (Table 3 and Supplementary Table S2), but not in African Americans (Supplementary Table S3). This study extends our earlier work on association of PDYN polymorphisms with cocaine dependence (Williams et al, 2007), and supports a previous study finding an association of these SNPs with alcohol dependence (Xuei et al, 2006). In that study, the Edenberg group found a strong association of the same 3'UTR SNP in a very large cohort of 1860 Caucasians.

Analysis of haplotypes revealed only one block of these three SNPs in both ethnic groups. There were only two major complementary haplotypes, TTC and CCT. Haplotype TTC was more frequent in Caucasian control subjects, whereas the haplotype CCT was associated with a risk for development of cocaine dependence or cocaine/alcohol codependence (Table 4). An earlier study showed that haplotype CCT was also overtransmitted to alcoholdependent individuals of Caucasian ancestry (Xuei et al, 2006).

Aside from the 68-bp tandem repeat variants in the PDYN promoter, the functionality of other PDYN SNPs has not been previously described. To test the hypothesis that the haplotypes TTC and CCT were associated with alterations in PDYN mRNA levels, we measured allelic expression of the gene in human postmortem brain tissues from eight subjects heterozygous for rs910079 using the SNaPshot assay. In this assay, quantitative measurements of differential mRNA allelic expression are based on a primerextension reaction by comparing the relative level of each variant of mRNA transcript in a tissue from individuals who are heterozygous for an expressed polymorphism (Yan et al, 2002; Bray et al, 2003; Pastinen et al, 2006). Each allele serves as an internal control against which expression of the other allele can be measured within each individual mRNA sample. The advantage of this ex vivo method is that alleles are expressed in their normal physiological environment (Pastinen and Hudson, 2004).

Our results demonstrate the presence of significant allelic differences in mRNA expression of PDYN in seven out of eight samples analyzed in both the caudate and nucleus accumbens regions (Figure 2 and Supplementary Table S5), with greater expression of the common rs910079 $\mathrm{T}$ allele and lower expression of the $\mathrm{C}$ allele. Because only two major complementary haplotypes (TTC and CCT) were found (Table 4 and Supplementary Table S4), the high LD of rs910079 with two other $3^{\prime}$ UTR SNPs (rs910080 and rs2235749) suggests that the CCT haplotype is associated with lower PDYN expression in the striatum. However, without further experimental data it is not clear which of these SNPs is functional. It is of interest that individual no. 553 did not show allelic difference in expression possibly due to having TT in rs910080 locus or having a different haplotype structure compared with the other seven subjects. The present study provides the first evidence that the SNP rs910079 in the gene may be a cis-acting polymorphism, related to differential $P D Y N$ gene expression in an allelespecific manner. Importantly, the allelic-gene expression assay was performed in the caudate and nucleus accumbens, which are principal brain regions in the rewarding effects of drugs of abuse (Koob and Kreek, 2007).

Moreover, the measurements of the total PDYN mRNA levels in the caudate from 43 postmortem brains demonstrated a strong effect of the TTC and CCT haplotypes. The subjects with homozygous diplotypes consisting of the 'protective' TTC haplotypes had significantly higher levels of PDYN mRNA compared with the mRNA levels in the subjects with homozygous diplotypes of 'risk' CCT haplotypes (Figure 3). It is of interest that the significant relationship observed between the genotypes and total PDYN mRNA levels was not dependent on ethnicity or other variables of postmortem tissues (Table $1 \mathrm{~b}$ and Supplementary Table S4). Gene expression profiles in postmortem tissues may be influenced by factors such as medical history, medication, immediate antemortem state, and agonal state of subjects as well as PMI (Atz et al, 2007). To reduce these effects in our study, assessments were made on brain tissue $\mathrm{pH}$ and quality of RNA preparations.

We have measured PDYN mRNA levels in the caudate first because rodent studies in our laboratory and others showed a robust response in this region to acute and chronic cocaine administration (eg Spangler et al, 1993; Daunais and McGinty, 1994; Yuferov et al, 2001), and no change was found in the nucleus accumbens. Our laboratory has long hypothesized that the dorsal striatum (caudate and putamen) is centrally involved in drug addiction. Also, elevated levels of PDYN mRNA in striatum of former cocaine addicts were reported in an earlier study (Hurd and Herkenham, 1993). Furthermore, neuroimaging of cocainedependent subjects has shown the largest dopamine changes in dorsal striatum, and the magnitude of these changes was correlated with self-reports of craving (Volkow et al, 2006).

The discovery of allelic PDYN expression differences raises the question of whether the $3^{\prime}$ UTR SNP rs910079 is functional or linked to other functional variants. The $3^{\prime} U T R$ of genes are rich in regulatory elements essential for the regulation of mRNA stability and degradation, nuclear transport, and translation (Mignone et al, 2002). These diverse regulatory roles are executed via cis-acting elements that interact with a multitude of trans-acting factors in a given cellular environment, including targeting by microRNAs (Xie et al, 2005; Chen et al, 2006). A recent study of the dopamine $\mathrm{D}_{1}$ receptor (DRD1) provided evidence that a $3^{\prime}$ UTR SNP, associated with nicotine dependence, causes a differential expression of a reporter gene, suggesting that the SNP is a functional polymorphism affecting DRD1 expression (Huang et al, 2008). Further studies of the promoter and $3^{\prime}$ UTR regulatory elements in $P D Y N$ mRNA are required to elucidate their functional roles.

Among the two variants in the PDYN promoter region analyzed in this study, only the -301A/G SNP (rs1997794) 
was in linkage with the cis-acting $3^{\prime}$ UTR SNP rs910079 in Caucasians (Figure 1). The minor G-allele of rs1997794 eliminates a putative binding site TGTGTCA for the AP-1 transcription factor. Because the G-allele of this SNP is more frequently associated with the risk haplotype CCT (Table 5), it may contribute to lower expression of the PDYN gene in cocaine dependent and cocaine/alcohol codependent subjects.

Animal studies have shown that dynorphin peptides can attenuate cocaine-induced increases in extracellular dopamine levels in reward-related areas of the brain (eg Claye et al, 1997; Zhang et al, 2004), reduce the rate of intravenous cocaine self-administration, and prevent the development of cocaine-induced conditioned place preference (Glick et al, 1995; Schenk et al, 1999; Zhang et al, 2004). It has been suggested that the dynorphin-KOPr system might be part of the counter-modulatory mechanisms of the brain after drug-induced dopaminergic stimulation, and dysregulation of this system may contribute to development of cocaine dependence and cocaine/alcohol codependence (Kreek et al, 2002; Koob and Kreek, 2007).

One limitation of this study is that no analysis of population stratification was performed. However, $91 \%$ of our control groups were described in recent studies from our laboratory (Nielsen et al, 2008; Levran et al, 2008; Levran et al, in preparation), showing that the two ethnic groups (Caucasians and African Americans) are quite homogenous and the self-identified ethnicities for the most part are accurate.

Future association studies in larger cohorts of welldefined ethnicity and phenotypes will be required to replicate our findings. It is not known whether the observed allele-specific alterations in PDYN mRNA abundance are linked to corresponding alterations in dynorphin peptide levels. Additional cis-acting elements in the PDYN gene may exist, particularly, cis-regulatory elements and epigenetic factors which may be involved in differential gene expression. A recent study of the keratin 1 gene (KRT1) expression in white blood cells suggests that allelic expression differences result from the cumulative contribution of multiple cis-regulatory sequences, interacting with both transcriptional activators and transcriptional repressors (Tao et al, 2006).

In summary, these results implicate PDYN polymorphisms as one of the genetic factors affecting susceptibility to develop cocaine dependence or cocaine/alcohol codependence. We provide additional evidence of association SNPs in the PDYN $3^{\prime} \mathrm{UTR}$ with cocaine dependence or cocaine/ alcohol codependence in Caucasians. The present study provides the first evidence that the cis-acting polymorphism (rs910079) in the PDYN 3'UTR may be involved in alterations of gene expression in an allele-specific manner. Furthermore, we demonstrate that SNPs and haplotypes associated with risk in vulnerability to develop cocaine dependence are related to decreased steady-state PDYN mRNA levels in the striatum.

The identification of PDYN variants that modify or predict levels of dynorphin mRNA in the brain may lead to better understanding of the role of dynorphins in the development of cocaine dependence and to improved strategies for prevention and pharmacological treatment of this disease.

\section{ACKNOWLEDGEMENTS}

We acknowledge K Bell, E Ducat, D Melia, B Ray, L Borg, P McHugh for recruiting, screening, and assessment of study subjects. We thank Daniel Perl (Alzheimer's Disease Research Center, The Mount Sinai Medical Center, New York, NY) for providing postmortem brain tissues. We are grateful to $M$ Randesi for sequencing assistance. This work was supported by grants from the National Institutes of Health: P60-DA05130 (MJK), R01-MH79880 (MJK), R24MH59724 (SM), AG05138 (D Perl), RR024143 (B Coller), R01- MH44292 (JO), and grants 30730057 and 30700442 from National Science Foundation of China (JO).

\section{DISCLOSURE/CONFLICT OF INTEREST}

All the authors, except JO, declare that, except for the income received from our primary employers, no financial support or compensation has been received from any individual or corporate entity over the past 3 years for research or professional service and there are no personal financial holdings that could be perceived as constituting a potential conflict of interests. One author, JO, wishes to declare that he personally receives book royalties from the Johns Hopkins University Press and that his laboratory receives funding from Hoffmann-La Roche Inc.

\section{REFERENCES}

Akil H, Owens C, Gutstein H, Taylor L, Curran E, Watson S (1998). Endogenous opioids: overview and current issues. Drug Alcohol Depend 51: 127-140.

Atz M, Walsh D, Cartagena P, Li J, Evans S, Choudary P et al (2007). Methodological considerations for gene expression profiling of human brain. J Neurosci Methods 163: 295-309.

Barrett JC, Fry B, Maller J, Daly MJ (2005). Haploview: analysis and visualization of $\mathrm{LD}$ and haplotype maps. Bioinformatics 21: 263-265.

Branch AD, Unterwald EM, Lee SE, Kreek MJ (1992). Quantitation of preproenkephalin mRNA levels in brain regions from male Fischer rats following chronic cocaine treatment using a recently developed solution hybridization assay. Brain Res Mol Brain Res 14: 231-238.

Bray NJ, Buckland PR, Owen MJ, O’Donovan MC (2003). Cis-acting variation in the expression of a high proportion of genes in human brain. Hum Genet 113: 149-153.

Bray NJ, O’Donovan MC (2006). Investigating cis-acting regulatory variation using assays of relative allelic expression. Psychiatr Genet 16: 173-177.

Buckland PR (2004). Allele-specific gene expression differences in humans. Hum Mol Genet 13: R255-R260.

Chen AC, LaForge KS, Ho A, McHugh PF, Kellogg S, Bell K et al (2002). Potentially functional polymorphism in the promoter region of prodynorphin gene may be associated with protection against cocaine dependence or abuse. Am J Med Genet 114: 429-435.

Chen JM, Férec C, Cooper DN (2006). A systematic analysis of disease-associated variants in the $3^{\prime}$ regulatory regions of human protein-coding genes II: the importance of mRNA secondary structure in assessing the functionality of $3^{\prime}$ UTR variants. Hum Genet 120: 301-333.

Claye LH, Maisonneuve IM, Yu J, Ho A, Kreek MJ (1997). Local perfusion of dynorphin A 1-17 reduces extracellular dopamine levels in the nucleus accumbens. NIDA Res Monogr 174: 113. 
Dahl JP, Weller AE, Kampman KM, Oslin DW, Lohoff FW, Ferraro TN et al (2005). Confirmation of the association between a polymorphism in the promoter region of the prodynorphin gene and cocaine dependence. Am J Med Genet 139B: 106-108.

Daunais JB, McGinty JF (1994). Acute and chronic cocaine administration differentially alters striatal opioid and nuclear transcription factor mRNAs. Synapse 18: 35-45.

Daunais JB, Roberts DC, McGinty JF (1993). Cocaine selfadministration increases preprodynorphin, but not c-fos, mRNA in rat striatum. Neuroreport 4: 543-546.

Gabriel SB, Schaffner SF, Nguyen H, Moore JM, Roy J, Blumenstiel B et al (2002). The structure of haplotype blocks in the human genome. Science 296: 2225-2229.

Gerfen CR (1984). The neostriatal mosaic: compartmentalization of corticostriatal input and striatonigral output systems. Nature 311: 461-464.

Gerfen CR (1992). The neostriatal mosaic: multiple levels of compartmental organization. Trends Neurosci 15: 133-139.

Glick SD, Maisonneuve IM, Raucci J, Archer S (1995). Kappa opioid inhibition of morphine and cocaine self-administration in rats. Brain Res 681: 147-152.

Horikawa S, Takai T, Toyosato M, Takahashi H, Noda M, Kakidani $\mathrm{H}$ et al (1983). Isolation and structural organization of the human preproenkephalin B gene. Nature 306: 611-614.

Huang W, Ma JZ, Payne TJ, Beuten J, Dupont RT, Li MD (2008). Significant association of DRD1 with nicotine dependence. Hum Genet 123: 133-140.

Hurd YL (1996). Differential messenger RNA expression of prodynorphin and proenkephalin in the human brain. Neuroscience 72: 767-783.

Hurd YL, Brown EE, Finlay JM, Fibiger HC, Gerfen CR (1992). Cocaine self-administration differentially alters mRNA expression of striatal peptides. Brain Res Mol Brain Res 13: 165-170.

Hurd YL, Herkenham M (1993). Molecular alterations in the neostriatum of human cocaine addicts. Synapse 13: 357-369.

Knight JC (2005). Regulatory polymorphisms underlying complex disease traits. J Mol Med 83: 97-109.

Koob G, Kreek MJ (2007). Stress, dysregulation of drug reward pathways, and the transition to drug dependence. Am J Psychiatry 164: 1149-1159.

Kreek MJ, Bart G, Lilly C, LaForge KS, Nielsen DA (2005). Pharmacogenetics and human molecular genetics of opiate and cocaine addictions and their treatments. Pharmacol Rev 57: 1-26.

Kreek MJ, LaForge KS, Butelman E (2002). Pharmacotherapy of addictions. Nat Rev Drug Discov 1: 710-726.

Kuzmin AV, Gerrits MA, Van Ree JM (1998). Kappa-opioid receptor blockade with nor-binaltorphimine modulates cocaine self-administration in drug-naive rats. Eur J Pharmacol 358: 197-202.

Le-Niculescu H, McFarland MJ, Mamidipalli S, Ogden CA, Kuczenski R, Kurian SM et al (2007). Convergent functional genomics of bipolar disorder: from animal model pharmacogenomics to human genetics and biomarkers. Neurosci Biobehav Rev 31: 897-903.

Levran O, Londono D, O'Hara K, Nielsen DA, Peles E, Rotrosen J et al (2008). Genetic susceptibility to heroin addiction: a candidate-gene association study. Genes Brain Behav 7: 720-729.

Mansour A, Fox CA, Meng F, Akil H, Watson SJ (1994). Kappa 1 receptor mRNA distribution in the rat CNS: comparison to kappa receptor binding and prodynorphin mRNA. Mol Cell Neurosci 5: 124-144.

McLellan AT, Kushner H, Metzger D, Peters R, Smith I, Grissom G (1992). The fifth edition of the addiction severity index. J Subst Abuse Treat 9: 199-213.

Mignone F, Gissi C, Liuni S, Pesole G (2002). Untranslated regions of mRNAs. Genome Biol 3: REVIEWS0004 Epub 2002 February 28.
Morley M, Molony CM, Weber TM, Devlin JL, Ewens KG, Spielman RS et al (2004). Genetic analysis of genome-wide variation in human gene expression. Nature 430: 743-747.

Negus SS, Mello NK, Portoghese PS, Lin CE (1997). Effects of kappa opioids on cocaine self-administration by rhesus monkeys. J Pharmacol Exp Ther 282: 44-55.

Nielsen DA, Ji F, Yuferov V, Ho A, Chen A, Levran O et al (2008). Genotype patterns that contribute to increased risk for or protection from developing heroin addiction. Mol Psychiatry 13: 417-428.

Parent A, Hazrati LN (1995). Functional anatomy of the basal ganglia. I. The cortico-basal ganglia-thalamo-cortical loop. Brain Res Brain Res Rev 20: 91-127.

Pastinen T, Ge B, Gurd S, Gaudin T, Dore C, Lemire M et al (2005). Mapping common regulatory variants to human haplotypes. Hum Mol Genet 14: 3963-3971.

Pastinen T, Ge B, Hudson TJ (2006). Influence of human genome polymorphism on gene expression. Hum Mol Genet 15: R9-R16.

Pastinen T, Hudson TJ (2004). Cis-acting regulatory variation in the human genome. Science 306: 647-650.

Purcell S, Neale B, Todd-Brown K, Thomas L, Ferreira MA, Bender $\mathrm{D}$ et al (2007). PLINK: a tool set for whole-genome association and population-based linkage analyses. Am J Hum Genet 81: 559-575.

Ray R, Doyle GA, Crowley JJ, Buono RJ, Oslin DW, Patkar AA et al (2005). A functional prodynorphin promoter polymorphism and opioid dependence. Psychiatr Genet 15: 295-298.

Sadée W, Dai Z (2005). Pharmacogenetics/genomics and personalized medicine. Hum Mol Genet 14: R207-R214.

Schenk S, Partridge B, Shippenberg TS (1999). U69593, a kappaopioid agonist, decreases cocaine self-administration and decreases cocaine-produced drug-seeking. Psychopharmacology (Berl) 144: 339-346.

Sivam P (1989). Cocaine selectively increases striatonigral dynorphin levels by a dopaminergic mechanism. J Pharmacol Exp Ther 250: 818-824.

Spangler R, Unterwald EM, Kreek MJ (1993). 'Binge' cocaine administration induces a sustained increase of prodynorphin mRNA in rat caudate-putamen. Brain Res Mol Brain Res 19: 323-327.

Steiner H, Gerfen CR (1998). Role of dynorphin and enkephalin in the regulation of striatal output pathways and behavior. Exp Brain Res 123: 60-76.

Storey JD (2002). A direct approach to false discovery rates. $J R$ Stat Soc, Ser B 64: 479-498.

Storey DJ, Taylor JE, Siegmund D (2004). Strong control, conservative point estimation and simultaneous conservative consistency of false discovery rates: a unified approach. $J R$ Stat Soc B 66: 187-205.

Storey JD, Tibshirani R (2003). Statistical significance for genomewide studies. Proc Natl Acad Sci USA 100: 9440-9445.

Tao H, Cox DR, Frazer KA (2006). Allele-specific KRT1 expression is a complex trait. PLoS Genet 2: e93.

Volkow ND, Wang GJ, Telang F, Fowler JS, Logan J, Childress AR et al (2006). Cocaine cues and dopamine in dorsal striatum: mechanism of craving in cocaine addiction. J Neurosci 26 : 6583-6588.

Wang JC, Grucza R, Cruchaga C, Hinrichs AL, Bertelsen S, Budde JP et al (2008). Genetic variation in the CHRNA5 gene affects mRNA levels and is associated with risk for alcohol dependence. Mol Psychiatry (15 April), doi: 10.1038/mp.2008.42, PMID: 18414406. [E-pub ahead of print].

Williams TJ, LaForge KS, Gordon D, Bart G, Kellogg S, Ott J et al (2007). Prodynorphin gene promoter repeat associated with cocaine/alcohol codependence. Addict Biol 12: 496-502.

Xie X, Lu J, Kulbokas EJ, Golub TR, Mootha V, Lindblad-Toh K et al (2005). Systematic discovery of regulatory motifs in human 
promoters and $3^{\prime}$ UTRs by comparison of several mammals. Nature 434: 338-345.

Xuei X, Dick D, Flury-Wetherill L, Tian HJ, Agrawal A, Bierut L et al (2006). Association of the kappa-opioid system with alcohol dependence. Mol Psychiatry 11: 1016-1024.

Yan H, Yuan W, Velculescu VE, Vogelstein B, Kinzler KW (2002). Allelic variation in human gene expression. Science 297: 1143.

Yuferov V, Zhou Y, LaForge KS, Spangler R, Ho A, Kreek MJ (2001). Elevation of guinea pig brain preprodynorphin mRNA expression and hypothalamic-pituitary-adrenal axis activity by 'binge' pattern cocaine administration. Brain Res Bull 55: 65-70.
Zhang Y, Butelman ER, Schlussman SD, Ho A, Kreek MJ (2004). Effect of the endogenous kappa opioid agonist dynorphin A(117) on cocaine-evoked increases in striatal dopamine levels and cocaine-induced place preference in $\mathrm{C} 57 \mathrm{BL} / 6 \mathrm{~J}$ mice. Psychopharmacology (Berl) 172: 422-429.

Zhang Y, Wang D, Johnson AD, Papp AC, Sadée W (2005). Allelic expression imbalance of human mu opioid receptor (OPRM1) caused by variant A118G. J Biol Chem 280: 32618-32624.

Zimprich A, Kraus J, Woltje M, Mayer P, Rauch E, Höllt V (2000). An allelic variation in the human prodynorphin gene promoter alters stimulus induced expression. J Neurochem 74: 472-477.

Supplementary Information accompanies the paper on the Neuropsychopharmacology website (http://www.nature.com/npp) 